Boise State University

ScholarWorks

Raptor Research Center Publications and

Presentations

Raptor Research Center

$1-2-2010$

\title{
Wintering Area DDE Source to Migratory White- Faced Ibis Revealed by Satellite Telemetry and Prey Sampling
}

Michael A. Yates

Boise State University

Mark R. Fuller

Forest and Rangeland Ecosystem Science Center

Charles J. Henny

Forest and Rangeland Ecosystem Science Center

William S. Seegar

Edgewood Research Development and Engineering Center

Jaqueline Garcia

Centro de Investigacion en Alimentacion y Desarrollo A.C. 


\title{
Wintering Area DDE Source to Migratory White-faced Ibis Revealed by Satellite Telemetry and Prey Sampling
}

\author{
Michael A. Yates ${ }^{1}$, Mark R. Fuller ${ }^{2}$, Charles J. Henny ${ }^{3}$, William S. Seegar ${ }^{4}$ and Jaqueline Garcia ${ }^{5}$ \\ ${ }^{1}$ Raptor Research Center at Boise State University, 2656 Wade St., Minden, NV 89423 USA corresponding author: \\ MYfalcon@charter.net \\ ${ }^{2}$ U.S. Geological Survey, Forest and Rangeland Ecosystem Science Center, Snake River Field Station, 970 Lusk St., \\ Boise, ID 83706 USA \\ ${ }^{3}$ U.S. Geological Survey, Forest and Rangeland Ecosystem Science Center, 3200 SW Jefferson Way, Corvallis, OR \\ 97331 USA \\ ${ }^{4}$ Edgewood Research Development and Engineering Center, Department of Army, Aberdeen Proving Ground, MD \\ 21010, USA \\ ${ }^{5}$ Centro de Investigacion en Alimentacion y Desarrollo A.C., Carretera al Varadero Nal. Km 6.6, A.P. 284, C.P. \\ 85480, Guaymas, Sonora, Mexico
}

\begin{abstract}
Locations of contaminant exposure for nesting migratory species are difficult to fully understand because of possible additional sources encountered during migration or on the wintering grounds. A portion of the migratory white-faced ibis (Plegadis chihi) nesting at Carson Lake, Nevada continues to be exposed to dichloro-diphenyldichloroethylene (DDE) with no change, which is unusual, observed in egg concentrations between 1985 and 2000. About 45 to $63 \%$ of the earliest nesting segment shows reduced reproductive success correlated with elevated egg concentrations of $>4 \mu \mathrm{g} / \mathrm{g}$ wet weight (ww). Local prey (primarily earthworms) near nests contained little DDE so we tracked the migration and wintering movements of 20 adult males during 2000-2004 to determine the possible source. At various wintering sites, we found a correlation $\left(\mathrm{r}^{2}=0.518, \mathrm{P}=0.0125, \mathrm{~N}=11\right)$ between DDE in earthworm composites and DDE in blood plasma of white-faced ibis wintering there, although the plasma was collected on their breeding grounds soon after arrival. The main source of DDE was wintering areas in the Mexicali Valley of Baja California Norte, Mexico, and probably the adjacent Imperial Valley, California, USA. This unusual continuing DDE problem for white-face ibis is associated with: the long-term persistence in soil of DDE; the earthworms' ability to bioconcentrate DDE from soil; the proclivity of white-faced ibis to feed on earthworms in agricultural fields; the species extreme sensitivity to DDE in their eggs; and perhaps its life history strategy of being a "capital breeder". We suggest surveying and sampling white-faced ibis eggs at nesting colonies, especially at Carson Lake, to monitor the continuing influence of DDE.

Key words: DDE; white-faced ibis; earthworms; North America; migration; satellite telemetry.
\end{abstract}

\section{Introduction}

The white-faced ibis (Plegadis chihi), hereafter referred to as ibis, is a wading bird that feeds primarily on invertebrates including earthworms in wetlands and irrigated croplands. The Intermountain West Waterbird Conservation Plan (Ivey and Herziger 2005) identifies this ibis as a species of moderate conservation concern in the Great Basin and Northern Rockies. Earnst et al. (1998) stated that concern was based on its small regional population size and the limited and dynamic nature of its wetland breeding habitat. The 1972-1988 ibis nesting population at Carson Lake, Nevada, in response to water conditions, varied from 0 pairs nesting in low water years 1974 and 1977 to 5000 pairs nesting in flood year 1985 (Henny and Herron 1989). Although contaminants were not mentioned as a threat by Ivey and Herziger (2005) or Earnst et al. (1998), the historical population decline of ibis was associated with dichloro-diphenyl-trichloroethane (DDT) contamination (Ryder and Manry 1994).

In 1997 the persistent occurrence of dichloro-diphenyldichloro-ethylene (DDE), the principal metabolite of DDT, in the eggs of ibis (Henny 1997) continued to pose a threat to those that nest at Carson Lake. Management options were limited because contaminant source(s) were unknown. DDE in eggs was highest in the earliest nesting cohort at Carson Lake, and the source was not the breeding grounds (Henny and Herron 1989); therefore the source was either from the migration routes or wintering areas, which were not fully delineated. DDE contamination above the reproductive effect level of $4 \mu \mathrm{g} / \mathrm{g}$ (ww) occurred in 45\% of the eggs collected at Carson Lake, Nevada in 1996 (Henny 1997). Henny and Herron (1989) reported white-faced ibis nests at Carson Lake with a sample egg containing 4-8 $\mu \mathrm{g} / \mathrm{g}$ (ww) DDE were $16.2 \%$ thinner than pre-DDT era eggshells and produced $30 \%$ fewer young than at nests with lower DDE concentrations. Nests with eggs containing higher DDE concentrations contained 
even thinner eggshells and produced fewer young. Of further concern, the source(s) of DDE affecting the Carson Lake ibis population might be affecting other bird species in the same region where ibis exposure occurs. DDT/DDE contamination in eggs from other ibis nesting populations in the west were generally lower than at Carson Lake, although eggshell thinning and cracked eggs were sometimes reported: Ruby Lake National Wildlife Refuge (NWR), NV; Malheur NWR, OR; southern Texas; northern Utah; Sacramento NWR, CA; Lower Klamath NWR, CA; Cibola NWR, AZ and Imperial Valley, CA (Capen 1977; Steele 1980; Henny et al. 1985, 2008; Custer and Mitchell 1989; Dileanis et al. 1992, 1996; King et al. 2003). Two notable exceptions were Cibola NWR, AZ, which in 2000 had DDE concentrations in eggs similar to those at Carson Lake, and Finney Lake Imperial Wildlife Area south of the Salton Sea NWR in the Imperial Valley, CA which had even higher concentrations in 1992. Thus, while the extent of DDE contamination in the range-wide ibis population remains fragmentary, the adverse effects of DDE are not limited to a portion of the Carson Lake breeding colony.

Bray and Klebenow (1988) reported that earthworms represented the majority of the ibis diet on a Great Basin breeding ground (68\% of volume and dry weight) with insect larvae (Libellulidae, Tabanidae, Lepidoptera) forming most of the remainder. Edwards and Jeffs (1974) reported that earthworms accumulated high burdens of organochlorine contaminants from the ingestion of contaminated soils. Furthermore, Callahan et al. (1991) quantified uptake of DDT and DDE in earthworms placed in contaminated soil, and suggested that whole body concentrations could affect earthworm predators.

Technology for radio tracking birds with satellite telemetry now allows study of potential sources of contamination on a global scale (e.g., Goldstein et al. 1999, Elliott et al. 2007). From a conservation perspective, it is important to understand the contaminant source because (1) a high percentage of the earliest nesting segment at Carson Lake between 1985 and 1996 contained DDE concentrations in eggs that adversely affected reproductive success (Henny and Herron, 1989) and (2) DDE concentrations were not declining over time, as had been reported for many other species (Henny 1997). Only six band recoveries in winter were available from nesting ibis banded in Nevada, and all six were recovered in western Mexico (3 Sinaloa-Nayarit, 3 Jalisco-Michoacan-Colima); those banded in Idaho showed a similar pattern with all reported from Mexico (Henny et al. 1985). In contrast, more recent color-marking at Carson Lake in 1994-1996 (Kelchlin 1997) resulted in winter re-sightings predominantly in the Salton Sea-Imperial Valley area of southern California $(n=8)$, but also the Lower Colorado River Valley ( $\mathrm{n}=4$ ), on or adjacent to the Bosque Del Apache NWR in New Mexico ( $n=2)$, Monterey County, CA ( $n=1)$, and Sinaloa, Mexico $(n=1)$. Sightings from Mexico were less likely, because notices about color-marked birds were not well distributed there. Therefore, the color-marking data were believed biased toward sightings in the United States; however, the re-sightings certainly indicated that some Carson Lake birds were wintering in the southwestern United States, including California. At about the same time, Shuford et al. (1996) reported an increase in the wintering population of ibis in California that began in the 1980s and increased sharply in the 1990s. We suspected that the ibis from Carson Lake were migrating to the southwestern United States and Mexico to winter, where a portion was being contaminated. The objectives of this study were to (1) use satellite telemetry to locate and describe the wintering areas for the early-nesting ibis population at Carson Lake; (2) evaluate burdens of DDE in individual ibis using blood plasma; and (3) determine if ibis DDE burdens were related to DDE contamination in earthworms or other invertebrates on their chosen wintering grounds.

\section{Materials and methods}

Capture, blood and egg sampling and instrumentation

With the earliest ibis nesting segment at Carson Lake having the highest DDE egg concentrations (Henny and Herron 1989, Henny 1997), that segment was selected for capture, blood sampling and equipping with transmitters. Surveys at Carson Lake to determine the nest locations of the earliest nesting cohort were conducted during late-March/early-April 2000 and 2003. Individual birds were captured from an air boat at night by spotlight and dip net, and immediately removed from the net (Schemnitz 1980). Males were selected because of their larger size and higher likelihood of successfully carrying the transmitter package. Furthermore, males would not be lowering DDE body concentrations by depositing it in eggs. Because ibis fly to the feeding areas and forage together in integrated flocks, diet at those areas is similar among genders. In 2000, an ibis egg from 10 different nests was collected for pesticide analyses for comparison with the earlier egg residue findings.

DDE concentrations were evaluated from blood plasma samples collected at the time transmitters were attached to the males. We subdivided individuals into three categories (i.e., high, medium and low concentrations) based on natural breaks in the blood DDE residue data. We treated earthworm residue data in the same manner. 
Logically, a match of high blood plasma DDE and high earthworm DDE concentrations provides evidence for an important DDE source on the wintering grounds. And, earthworm residue data from the migration route provided supplementary information. The blood plasma and earthworm DDE data were evaluated with regression analyses.

Captured birds were retained in poultry crates, and assessed for health (determined by body mass and subjective overall condition). Twenty adult male ibis that weighed $550-677 \mathrm{~g}$ were judged to be in excellent condition and were radio marked (10 each in 2000 and 2003) and banded (US Geological Survey leg bands; Gustafson et al. 1997). Blood samples ( $\sim 1 \mathrm{ml})$ were obtained from the brachial vein via syringe and 27 -gauge needle (Redig 1993) and stored in a sterile heparinized vacutainer. Whole blood was separated by centrifuge, with plasma drawn via sterile pipette, frozen in sterile cryogenic vials, and transported on dry ice to the Analytical Control Facility, USGS Patuxent Wildlife Research Center. Platform Transmitter Terminals (PTTs) weighing 20 g (North Star Science and Technology, LLC) were attached as backpacks (Snyder et al. 1989) with teflon ribbon (2000) or neoprene (2003) harnesses fitted to each bird. After blood sampling, radio marking and banding, each bird was released near the capture site. All protocols were approved by Boise State University's Institutional Animal Care and Use Committee and conducted under necessary permits acquired from state and federal authorities.

Satellite telemetry and data management

Tracking via satellites was based on the Argos System (2007-8) (https://www.argos-system.org). Argos estimates the location and the distribution within which the estimate lies. The standard deviation of this distribution estimates the accuracy of the location and is used to categorize it into a Location Class (LC). Class 1 locations are nominally better than $1000 \mathrm{~m}$ on both axes, with a $1500 \mathrm{~m}$ radius; and Class 2 at better than $350 \mathrm{~m}$, on both axes with a $500 \mathrm{~m}$ radius. Class 3 locations are considered the most accurate, and are estimated at better than $150 \mathrm{~m}$ on both axes, with a $250 \mathrm{~m}$ radius. Error estimation of a class 0 location is higher than $1.5 \mathrm{~km}$, and "A," "B," and "Z" location classes had no estimated location accuracy. We used Class 1-3 locations (and Class 0 locations, when evaluated in the context of previous and subsequent Class 1-3 locations) to describe broad scale movements.

PTT transmission cycles initially were programmed to verify proper operation of the PTT and then to conserve battery power until we expected birds to be en route to the winter range. In 2000, PTTs were set for transmission periods of: (1) $6 \mathrm{hrs}$ each day for the first 6 days; (2) $6 \mathrm{hrs}$ of every $342 \mathrm{hrs}$ until October 2000; and (3) $8 \mathrm{hrs}$ of every $77 \mathrm{hrs}$ until batteries were depleted. Based on 2000 results, 2003 PTTs were programmed to maximize recovery of full battery function after the long pre-migratory period of relatively infrequent transmissions. We programmed 2003 PTTs to transmit: (1) $8 \mathrm{hrs}$ of every $248 \mathrm{hrs}$ until the beginning of November; (2) $8 \mathrm{hrs}$ of every $24 \mathrm{hrs}$ for three days to restore maximum battery condition; (3) $8 \mathrm{hrs}$ of every $111 \mathrm{hrs}$ until early March 2004; and (4) 8 hours of every $163 \mathrm{hrs}$ until mid-May 2004, at which time they would deactivate. Location and sensor (e.g., temperature, activity) data were received electronically from Argos, processed by Earthspan with files created for analyses and use in ESRI ArcGIS Geographic Information Systems software (http://www.esri.com/).

Invertebrate sampling

Invertebrates were sampled at wintering sites between late January and early March 2001, 2002 and 2004. Samples were collected when ibis were at their wintering sites, which were identified by the mean of the Class 3 telemetry locations of each ibis successfully tracked to the wintering grounds. We traveled to the site, observed the closest group of ibis and sampled invertebrates where the ibis were feeding. We recorded GPS location and land use where the ibis were feeding, and we recorded other avian species using the site. For each site, samples were collected at $3-7$ feeding locations or where earthworms could be found near ibis foraging locations. Sample locations at a site were at least $400 \mathrm{~m}$ apart unless habitat/land use was judged unsuitable as feeding habitat. In the extreme case, because of limited access on a refuge, one sampling location was $16 \mathrm{~km}$ from the mean Class 3 site. The primary objective was to collect earthworms (Family Lumbricidae), but also other aquatic worms, copepods, insects and their larvae. Forceps were used in collecting and processing the smaller invertebrates. When earthworms of sufficient size and number were present, the collection of a composite of $\geq 15 \mathrm{~g}$ was made. Mean DDE concentrations in earthworms for each ibis wintering area were based on 3 to 7 composites. For the smaller, more difficult to collect invertebrates, approximately $2 \mathrm{~g}$ composites of all species combined were collected. Samples were rinsed in distilled water and preserved as composites in chemically cleaned glass bottles, frozen at $20^{\circ} \mathrm{C}$ and transported to the analytical laboratory on dry ice. Most non-earthworm prey species were collected in 2001; however, based on the low residue concentrations initially obtained for this group, invertebrate collections in the winter of 2004 emphasized earthworms. 
Analytical Chemistry

Blood, eggs, and invertebrate samples were analyzed for organochlorine pesticides, their metabolites, and polychlorinated biphenyls (PCBs). Methods are described in Cromartie et al. (1975) and Kaiser et al. (1980) with all concentrations presented in the tables and figures on a wet weight basis. Recoveries of spiked samples ranged from 92 to $110 \%$. Residue data were not corrected for rate of recovery and analytical results were approved by the Patuxent Analytical Control Facility. Only invertebrate samples collected in 2004 were analyzed at the Great Lakes Institute of Environmental Research (GLIER) at the University of Windsor, Ontario, Canada, using methods described in detail in GLIER (1995). Methodology for extraction and cleanup was checked by running sample blanks, replicate samples and certified reference samples provided by the Canadian Wildlife Service (CWS). The percent lipid in each sample was determined for all earthworm composites, but only for ibis blood plasma collected in 2003. Organochlorine pesticide analyses met QA/QC standards of the CWS with spiked recoveries ranging from 78 to $130 \%$ with no adjustment made for recovery. Egg residue concentrations were adjusted to a fresh wet weight based on egg volume (Stickel et al. 1973).

\section{Results}

Egg residues

DDE concentrations in the eggs of the early nesting ibis at Carson Lake in 2000 remained as high (geo. mean $3.63 \mu \mathrm{g} / \mathrm{g}$ [ww]), Table 1) as in 1985, 1986, and 1996 (Henny 1997), with 6 of 10 eggs containing $\geq 4 \mu \mathrm{g} / \mathrm{g}$, which is the level that adversely affects productivity (Henny and Herron 1989). Except for dieldrin, using the detection limits reported in the earlier studies, all other contaminants were below the detection limit in 2000. However, HCB, o, $p^{\prime}$ DDD and p, $p^{\prime}$ DDD were documented in 2000 when lower detection limits were used (Table $1)$.

\section{Blood plasma DDE concentrations}

Seventeen of the 20 ibis had detectable blood plasma DDE concentrations, ranging from 0.011 to 0.990 $\mu \mathrm{g} / \mathrm{g}$ (Table 2). Natural breaks in the DDE distribution resulted in three subdivisions: high ( $\geq 0.623 \mu \mathrm{g} / \mathrm{g}$ ), medium $(0.116$ to $0.380 \mu \mathrm{g} / \mathrm{g})$ and low $(\leq 0.076 \mu \mathrm{g} / \mathrm{g})$. Therefore, among 20 ibis plasma samples, 6 were categorized as high, 5 medium, and 9 low for DDE.

Radio tracking to wintering areas

Fifteen of the 20 PTTs began to produce good location estimates after the change to more frequent transmissions, and 12 ibis were successfully tracked to wintering sites. PTT sensor data (e.g., activity, voltage) suggested that three died or shed their transmitters en route. Wintering areas were located for 4 birds with high DDE levels ( 0.623 to $0.911 \mu \mathrm{g} / \mathrm{g}$ ), 3 birds with medium ( 0.116 to $0.380 \mu \mathrm{g} / \mathrm{g}$ ), and 5 birds with low (0.011 to 0.063). Wintering sites ranged from the northern Central Valley of California to the state of Jalisco in central Mexico (Fig 1).

Invertebrates and bird observations at wintering sites

Sampling trips were conducted in early 2001, 2002 and 2004; all 12 confirmed wintering sites were ultimately visited during these trips. Among 17 non-earthworm composite samples collected at 6 wintering sites, 14 contained $<10 \mu \mathrm{g} / \mathrm{kg}$ (ww) DDE, with the highest $42 \mu \mathrm{g} / \mathrm{kg}$. In 2001 and 2002 only 9 of 22 samples collected were earthworm composites. The initial analytical results and a literature review indicated we should focus future sampling on earthworm composites, and we did so in 2004 (43 of 47 samples). Some 2001 wintering sites were revisited to acquire necessary earthworm composites to represent 11 of the 12 identified winter sites.

Results of the 52 composites of earthworms collected at 11 wintering sites (Table 2, Fig. 1) clearly showed differing DDE concentrations among wintering sites sampled. Mean DDE concentrations, based upon three to seven composites, varied from 5.7 to $340 \mu \mathrm{g} / \mathrm{kg}$ (ww), with three sets of composites showing high means (range 198 - 340 $\mu \mathrm{g} / \mathrm{kg}$ ). At sites where earthworms had high DDE concentrations, 13 other species of birds were observed, but earthworms are not believed to be a major portion of any of their diets (Martin et al. 1951, Birds of North America Series - http://bna.birds.cornell.edu/bna) (Fig.1, Table 3). 
A log-log relationship $\left(\mathrm{r}^{2}=0.518, \mathrm{P}=0.0125\right)$ was found between DDE in ibis blood plasma (ww) collected on the breeding grounds soon (about 23 days after first arrival in 2000) after arrival from wintering areas, and DDE in earthworms (ww) from the wintering grounds (Fig. 2). We were uncertain of the first arrival date in 2003. Using our categories for DDE concentrations for an additional descriptive assessment of the data (Table 2), three of four ibis with high DDE in blood plasma also wintered at sites with high DDE in earthworms (all in Mexicali Valley, Mexico) (Table 2). The exception was No. 41308, but it spent at least 11 days and perhaps up to 3 weeks in the general vicinity of the Mexicali Valley before eventually migrating farther south and wintering in Guanajuanto, Mexico where DDE was low in earthworms (Fig.3). All three ibis with medium concentrations of DDE in blood plasma wintered at sites with medium DDE in earthworms (Yuba City, Norco and Bakersfield, all in California). Finally, three of four ibis with low DDE concentrations in blood plasma wintered at sites with low DDE in earthworms (Gustine, CA; Los Banos, CA; Sinaloa, Mexico) with the other wintering at Princeton, CA with medium earthworm concentrations (Table 2). Perhaps most important, all four ibis with high DDE concentrations in blood plasma either wintered or spent time in the US-Mexico border region which includes the southern portion of the Imperial Valley of California and the Mexicali Valley of Mexico (Fig. 3).

\section{Discussion}

White-faced ibis egg concentrations of DDE in 2000 at Carson Lake were still high and showed no change since 1985. Therefore, the source of the DDE needed to be determined because DDE concentrations in earthworms from the stomachs of ibis on the breeding grounds contained little DDE (below detection limit, $<100 \mu \mathrm{g} / \mathrm{kg}$ [ww]; Henny and Herron 1989). Earthworms are a primary food source of ibis (Bray and Klebenow 1988, Ryder and Manry 1994), and earthworms are known to bioaccumulate DDE (Beyer and Gish 1980). DDE concentrations in non-earthworm composites were all considered low, and of limited usefulness in assessing regional contaminant patterns, but at the same time, further documented the importance of earthworms as a DDE source. Satellite telemetry of blood-sampled ibis and an evaluation of earthworms collected on wintering sites of ibis indicated that a wintering area near the California-Mexico (Imperial Valley-Mexicali Valley) border was the likely source of the comparatively high DDE concentrations found in a segment of the population nesting at Carson Lake.

All but one ibis showed good agreement between DDE concentrations in blood plasma (ww) collected soon after their arrival on the breeding grounds (during the egg laying period) and DDE in earthworms (ww) on their wintering sites as evidenced by the good correlation $\left(\mathrm{r}^{2}=0.518, \mathrm{~N}=11, \mathrm{P}=0.0125\right)$ in Fig. 2 . The one ibis that spent time in the border region, but eventually wintered farther south in Mexico was the only outlier in the data set, that is, it had a high plasma DDE concentration, but eventually wintered farther south in Mexico where earthworm concentrations were generally low. We believe this outlier bird could have spent adequate time in the border area to accumulate high DDE in its plasma, perhaps more likely during its spring migration immediately before returning to Carson Lake. Note, with the one outlier removed, the relationship between ibis exposure (as measured by DDE in plasma) and wintering ground earthworm concentrations (ww) greatly improves $\left(\mathrm{r}^{2}=0.820, \mathrm{P}=0.0003, \mathrm{~N}=10\right)$. With the percent lipid content available $(0.75$ to $2.18 \%$ ) for all earthworm composites, the earthworms could be also evaluated on a lipid basis. The log-log relationships between blood plasma (ww) and earthworms (lipid weight) were very similar to the earthworm wet weight findings (with outlier, $\mathrm{r}^{2}=0.449, \mathrm{P}=0.0240, \mathrm{~N}=11$; without outlier $\mathrm{r}^{2}=0.789, \mathrm{P}=0.0006, \mathrm{~N}=10$ ). The limited information on ibis fidelity to migrations routes in autumn and spring and to wintering areas is a data gap that needs better understanding; however, with or without including the outlier, the data indicate that wintering areas are an important source of DDE found in ibis eggs at Carson Lake, Nevada.

The fact that prey other than earthworms contained uniformly low or no DDE further points to the earthworm as the principal source of DDE for ibis. The esophagi of white-faced ibis collected, but only when eating earthworms, also contained substantial amounts of soil (Bray and Klebenow 1988). Thus, the direct intake of soil associated with earthworm ingestion could also contribute to their DDE burden. The wintering source of the DDE reported in this study contrasts with the findings from a similar study of migratory ospreys (Pandion haliaetus) where the nesting area was the major source of DDE (Elliott et al. 2007). Additionally, DDE contamination of other bird species has been linked to exposure on the breeding grounds (e.g., Elliott et al. 1994, Harris et al. 2000, Richards et al. 2005). Therefore, no generalizations can be made about sources of contaminant exposure in migratory species (i.e., findings can vary from species to species). The discussion of life history theory (Houston et al. 2007) as it pertains to contaminant exposure has not received much attention. At least part of the different species 
responses may be related to breeding strategies. The osprey is apparently an "income" breeder producing eggs from locally acquired lipid and protein during the 3-4 weeks on the breeding area before egg laying (Elliott et al. 2007). In contrast, the white-face ibis appears to be a "capital breeder" that uses energy stores accumulated at an earlier time (wintering area) because it lays eggs only a few days after arrival on the breeding grounds (Ryder and Manry 1994, personal observations).

Additional evidence of a pattern of relatively high concentrations of DDE in the Imperial Valley and Mexicali Valley, compared to farther north or farther south, is apparent from studies of waterfowl (Ohlendorf and Miller 1984, Mora et al. 1987). Mora (1991) also reported elevated DDE concentrations (geo. mean $3.2 \mu \mathrm{g} / \mathrm{g} w w$ ) in 50 cattle egret (Bubulcus ibis) eggs collected in 1987-88, but with no serious effect on reproductive rates (apparently a less sensitive species). He strongly suggested that heavy past agricultural use of DDT in northwestern Mexico resulted in significant amounts of DDE remaining in the environment. DDT was widely used as a pesticide for agriculture in California and in the Mexicali Valley, Mexico until it was banned in 1972 and 1978 respectively (Extoxnet 1994, Fertilizantes Mexicanos, S.A. 1981). DDT and its metabolites can remain in the soil for long periods. Estimates of the half-life of DDT range from $2-17$ years (Extoxnet 1994), and that of DDE for 15 years. Nash and Woolsen (1967) found that 39\% of an original application remained in soil 17 years later, while Morrison et al. (2000) reported that $30 \%$ of DDT applied in one soil type 49 years earlier was still bio-available to earthworms. Setmire et al. (1993) found DDE concentrations in biota from freshwater rivers and drains around the Salton Sea and Imperial Valley to be the highest documented in California, and ibis had some of the highest concentrations in birds from the valley.

The use of agriculture fields for feeding by ibis (Bray and Klebenow 1988, Shuford et al. 1996, Blanco and Rodriguez-Estrella 1998, pers. observation) makes them especially susceptible to DDT from historical use. Although none of the telemetry-equipped ibis actually wintered in the Imperial Valley of California, given the area's topography, agricultural history, and use by ibis (including at least three of the four with high plasma DDE), that locale is also implicated as a source for DDE affecting the Carson Lake population. Shuford et al. (2002) considered the Salton Sea area, within the Imperial Valley, as a primary wintering area for white-faced ibis in western North America. Henny et al. (2008) reported DDE concentrations in five ibis eggs collected at the southern end of the Salton Sea in the Imperial Valley in 1992 that were much higher (geometric mean $11.0 \mu \mathrm{g} / \mathrm{g}$ ww) than at Carson Lake in 2000 (3.63 $\mu \mathrm{g} / \mathrm{g} \mathrm{ww}$ ) (Table 1). The Imperial Valley nesting colony no longer existed in 2004 (Henny, unpublished data).

Historical DDT applications also were particularly intensive in orchards (Blus et al. 1987), and we might expect to find parallel scenarios there with earthworm-eating species. Johnson et al. (1976) and Wheelwright (1986) stated that American robins (Turdus migratorius) forage primarily on earthworms before and during the breeding season, and Gill et al. (2003) found that American robins nesting decades after the last use of DDT in British Columbia orchards laid eggs with geometric mean total DDT (but mostly DDE) residues 44 times higher (48.6 vs. $1.10 \mu \mathrm{g} / \mathrm{g}$, ww) than those nesting in non-orchard habitats. However, in spite of the extremely high DDE concentrations found in eggs from the orchards, the robins (unlike ibis where $4 \mu \mathrm{g} / \mathrm{g} w \mathrm{w}$ in eggs causes reproductive problems, Henny and Herron 1989) were not especially sensitive and reproductive success did not appear negatively affected (Gill et al. 2003). Thus, the relative sensitivity differences among species protected the robin, but made the ibis susceptible to egg shell thinning and diminished reproductive performance. The brown pelican (Pelecanus occidentalis) is one of the few species more sensitive to DDE in eggs $(3 \mu \mathrm{g} / \mathrm{g}$ ww associated with near total reproductive failure, Blus 2003) than the white-faced ibis.

\section{Conclusions}

By understanding the contaminant source(s), management efforts can be improved and future research efforts prioritized. We conclude that the Mexicali Valley and adjacent Imperial Valley regions are the areas where wintering white-faced ibis from central Nevada are most exposed to DDE. Many avian species share the migration routes and wintering area habitat with the ibis, including at least 13 species seen during the Mexicali Valley collecting trip. However, none of these species are dependent upon earthworms; therefore, they are not expected to have similar DDE problems. The question might be asked, what about DDE effects on fish-eating birds in the region? Egg residue data from great egrets (Ardea alba) and black-crowned night-herons (Nycticorax nycticorax), which consume some fish in their diet, are available from the nearby Salton Sea in the Imperial Valley of southern California. During the 1980s, 1990s and 2004, both species showed fairly consistent DDE residue declines with associated increases in eggshell thickness (Henny et al. 2008). Thus, the ibis is perhaps unique in its difficulties associated with DDE, and might represent the worst-case scenario for continuing DDE problems. The plight of a portion of the ibis population in the west results from: (1) extreme sensitivity to DDE in their eggs compared to 
other species; (2) their extensive use of agricultural fields for feeding; (3) a diet high in earthworms, which are effective bioconcentrators of DDE from soils; and (4) perhaps its life history strategy of being a "capital breeder". Many factors affect the duration that DDT and DDE remain in soil after application (Hitch and Day 1992, Harris et al. 2000), and it is unknown how long this DDE threat to a portion of the Carson Lake population will persist. We have no evidence of residue declines between 1985 and 2000 at Carson Lake. It is clear that other species, including those nesting or wintering with the ibis, but feeding on other food sources, have shown much improvement in production accompanied by decreases in DDE concentrations during the last two decades (e.g., Henny et al. 1985, Henny et al. 2008, Henny et al. 2009).

With broad scale remediation of DDT and DDE in soils not an option (e.g., Foght et al. 2001), several research and management actions can be considered toward better understanding and monitoring the present influence of DDE. To learn where "at risk" ibis nest, wintering birds could be bled and radio tracked from the Imperial Valley-Mexicali Valley region. Also, a sample egg from a series of their nests, and especially from Carson Lake, can be evaluated for DDE contamination, perhaps at 5-year intervals, to monitor possible long-term changes in DDE concentrations. Monitoring the abundance of nesting ibis is complicated by their nomadic behavior whereby they establish new nesting colonies in response to changing water conditions in the Great Basin (Henny and Herron 1989). Thus, Earnst et al. (1998) recommend monitoring and management on a regional scale. At the regional scale, population monitoring that includes organochlorine contaminants, environmental variability and ibis demographics (e.g., Gervais and Anthony 2003) could alert managers to a decline in the western region white-faced ibis population.

\section{Acknowledgments}

Primary funding was provided by the Department of Defense's Legacy Resource Management Program. Linda Schueck and Branden Johnson of the USGS and Jim Dayton, Blake Henke, and Jack Cibor of Earthspan provided invaluable assistance in many ways. The U.S. Fish and Wildlife Service (USFWS) provided funding for some chemical analyses. The Stillwater National Wildlife Refuge (USFWS), and the Nevada Department of Wildlife provided considerable resources, time and capture expertise. We wish especially to recognize Bill Henry of the former, and Larry Neel, Gary Herron, Pete Bradley, and Jenni Jeffers of the latter. Eduardo Santana and Rodrigo Esparza assisted with the critical task of collecting invertebrates and recording other avian species associated with the ibis in Mexico. Mary Gustafson of the Bird Banding Laboratory (USGS) graciously accommodated our request for the PTT/body weight ratio under our auxiliary marking permit. Capture and processing expertise was also generously provided by Ali Chaney and Jennifer Newmark of the Nevada Natural Heritage Program, and by Bob Goodman and Brian McDonald. Eric Kelchlin kindly shared his expertise on the species during the planning stage. We thank Susan Earnst, Miguel Mora, and two reviewers for useful suggestions to improve our manuscript.

\section{References}

Argos (2007-8) Online Argos User's Manual. CLS, Ramonville Saint-Agne, France. <https://www.argossystem.org/manual/>

Birds of North America (Poole A Gill F, eds), Cornell Lab Ornithology and Acad Nat Sci. Ithaca, NY and Philadelphia, PA (Misc. Species Accounts)

Beyer WN, Gish CD (1980) Persistence in earthworms and potential hazards to birds of soil applied DDT, dieldrin and heptachlor. J Applied Ecol 17:295-307

Blanco G Rodriguez-Estrella R (1998) Human activity may benefit white-faced ibises overwintering in Baja California Sur, Mexico. Colonial Waterbirds 21:274-276 
Blus LJ (2003) Organochlorine pesticides. In: Hoffman DJ, Rattner BA, Burton GA, Jr. Cairns J, Jr. (eds). Handbook of ecotoxicology, second ed. Lewis Publishers, Boca Raton, FL, Pages 313-339

Blus LJ, Henny CJ, Stafford CJ, Grove RA (1987) Persistence of DDT and metabolites in wildlife from Washington State orchards. Arch Environ Contam Toxicol 16:467-476

Bray MP, Klebenow DA (1988) Feeding ecology of white-faced ibises in a Great Basin valley, USA. Colonial Waterbirds 11:24-31

Callahan CA, Menzie CA, Burmaster DE, Wilborn DC, Ernst T (1991) On-site methods for assessing chemical impact on the soil environment using earthworms: A case study at the Baird and McGuire Superfund Site, Holbrook, Massachusetts. Environ Toxicol Chem 10:817-826

Capen DE (1977) The impact of pesticides on the white-faced ibis. PhD Dissertation. Utah State Univ, Logan, UT Cromartie E, Reichel WL, Locke LN, Belisle AA, Kaiser TEG, Lamont TG, Mulhern BM, Prouty RMS, Swineford DM (1975) Residues of organochlorine pesticides and polychlorinated biphenyls and autopsy data for bald eagles, 1971-72. Pestic Monit J 9:11-14

Custer TW, Mitchell CA (1989) Organochlorine contaminants in white-faced ibis eggs in southern Texas. Colonial Waterbirds 12:126-129

Dileanis PD, Sorenson SK, Schwarzbach SE, Maurer TC (1992) Reconnaissance investigation of water quality, bottom sediment, and biota associated with irrigation drainage in the Sacramento National Wildlife Refuge Complex, California, 1988-89. U.S. Geol. Surv. Water-Resour Invest Rept 92-4036

Dileanis PD, Schwarzbach SE, Bennett J (1996) Detailed study of water quality, bottom sediment, and biota associated with irrigation drainage in the Klamath Basin, California and Oregon, 1990-92 (abs). U.S. Geol. Surv. Water-Resour Invest Rept 95-4232

Earnst SL, Neel L, Ivey GL, Zimmerman T (1998) Status of the white-faced ibis: Breeding colony dynamics of the Great Basin population, 1985-1997. Colonial Waterbirds 21:301-313

Edwards CA, Jeffs, K (1974) Rate of uptake of DDT from soil by earthworms. Nature 247:158

Elliott JE, Martin PA, Arnold TW, Sinclair PH (1994) Organochlorines and reproductive success of birds in orchard and non-orchard areas of central British Columbia, Canada, 1990-91. Arch Environl Contam Toxicol $26: 435-443$ 
Elliott JE, Morrissey CA, Henny CJ, Inzunza ER Shaw P (2007) Satellite telemetry and prey sampling reveal contaminant sources to Pacific Northwest Ospreys. Ecol Applic 17:1223-1233

Extoxnet (1994) DDT Pesticide Management Education Program, Cornell University, Ithaca, NY Fertilizantes Mexicanos SA (1981) Plan de desarrollo de Fertimex en la produccion, formulacion y comercializacion de insecticidas. Volume II, Gerencia General de Programacion y Desarrollo, Mexico, Distrito Federal.

Foght J, April T, Briggar K, Aislabie J (2001) Bioremediation of DDT contaminated soils: A review.

Bioremediation J 5:225-246

Gervais JA, Anthony RG (2003) Chronic organochlorine contaminants, environmental variability, and the demographics of a burrowing owl population. Ecol Applic 13:1250-1262

Gill HLK, Cheng KM, Elliott JE (2003) An assessment of DDT and other chlorinated compounds and the reproductive success of American robins (Turdus migratorius) breeding in fruit orchards. Ecotoxicology $12: 113-123$

Great Lakes Institute for Environmental Research (GLIER) (1995) Methods and procedures quality manual, first ed.. Great Lakes Institute for Environmental Research, Univ Windsor, Windsor, Ontario, Canada

Goldstein MI, Lacher TE Jr, Woodbridge B, Bechard MJ, Canavelli SB, Zaccagnini ME, Cobb GP, Scollon EJ, Tribolet R,Hooper MJ (1999) Monocrotophos-induced mass mortality of Swainson's hawks in Argentina, 1995-96. Ecotoxicology 8:201-214

Gustafson ME, Hildenbrand J, Metras L (1997) The North American bird banding manual (electronic version). Version 1.0, Laurel, MD

Harris ML, Wilson LK, Elliott JE, Bishop CA, Tomlin AD, Henning KV (2000) Transfer of DDT and metabolites from fruit orchard soils to American robins (Turdus migratorius) twenty years after agricultural use of DDT in Canada. Arch Environl Contam Toxicol 39:205-220

Henny CJ (1997) DDE still high in white-faced ibis eggs from Carson Lake, Nevada. Colonial Waterbirds 20:478484

Henny CJ, Herron GB (1989) DDE, selenium, mercury, and white-faced ibis reproduction at Carson Lake, Nevada. J Wildl Manag 53:1032-1045

Henny CJ, Anderson TW, Crayon JJ (2008) Organochlorine pesticides, polychlorinated biphenyls, metals and trace elements in waterbird eggs, Salton Sea, California, 2004. Hydrobiologia 604:137-149 
Henny C, Blus LJ, Hulse CS (1985) Trends and effects of organochlorine residues on Oregon and Nevada wading birds, 1979-83. Colonial Waterbirds 8:117-128

Henny CJ, Yates MA, Seegar WS (2009) Dramatic declines of DDE and other organochlorines in spring migrant peregrine falcons from Padre Island, Texas, 1978-2004. J Raptor Res 43:37-42

Hitch RK, Day HR (1992) Unusual persistence of DDT in some western USA soils. Environ Contam Toxicol 48:259-264

Houston AI, Stephens PA, Boyd IL, Harding KC, McNamara JM (2007) Capital or income breeding? A theoretical model of female reproductive strategies. Behav Ecol 18:241-250

Ivey GL, Herziger CP (2005) Intermountain west region waterbird conservation plan. Intermountain West Joint Venture, West Valley City, UT

Kaiser TE, Reichel WL, Locke LN, Cromartie E, Krynitsky AJ, Lamont TG, Mulhern BM, Prouty RM, Stafford CJ, Swineford DM (1980) Organochlorine pesticides, PCB, PBB residues and necropsy data for bald eagles from 29 states - 1975-77. Pestic Monit J 13:145-149

Johnson EV, Mack GL, Thompson DQ (1976) The effects of orchard pesticide applications on breeding robins. Wilson Bul 88:16-35

Kelchlin EP (1997) Habitat selection and reproductive success of white-faced ibis in the Carson River Basin, Nevada. Final Progress Report. Stillwater Nat Wildl Refuge, Fallon, NV

King KA, Zaun BJ, Schotborgh HM, Hurt C (2003) DDE-induced eggshell thinning in white-faced ibis: A continuing problem in the western United States. Southwestern Nat 48:356-364

Martin AC, Zim HS, Nelson AL (1951) American wildlife and plants-- A guide to wildlife food habits. McGrawHill Book Co., New York

Mora MA (1991) Organochlorines and breeding success in cattle egrets from the Mexicali Valley, Baja California, Mexico. Colonial Waterbirds 14:127-132

Mora MA, Anderson DW, Mount ME (1987) Seasonal variation of body condition and organochlorines in wild ducks from California and Mexico. J Wildl Manag 51:132-141

Morrison DE, Robertson BK, Alexander M (2000) Bioavailabilty to earthworms of aged DDT, DDE, DDD, and dieldrin in soil. Environ Sci Technol 34:709-713

Nash RG, Woolson EA (1967) Persistence of chlorinated hydrocarbon insecticides in soils. Science 157:924-927 
This is an author-produced, peer-reviewed version of this article. The final publication is available at www.springerlink.com. Copyright restrictions may apply. doi: 10.1007/s10646-009-0400-8

Ohlendorf HM, Miller MR (1984) Organochlorine contaminants in California waterfowl. J Wildl Manage 48:867877

Redig PT (1993) Medical management of birds of prey. The Raptor Center, Univ Minnesota, St. Paul, MN

Richards NL, Mineau P, Bird DM (2005) A risk assessment approach to DDE exposure based on the case of the eastern screech-owl (Megascops asio) in apple orchards of southern Quebec, Canada. Arch Environ Contam Toxicol 49:403-409

Ryder RR, Manry DE (1994) White-faced ibis (Plegadis chihi). In: Poole A, Gill F eds, The birds of North America. Cornell Lab Ornithology and Acad Nat Sci, Ithaca, NY And Philadelphia, PA

Schemnitz SD (ed) (1980) Wildlife management techniques manual, fourth ed. Wildl Soc, Washington, DC

Setmire JG, Schroeder RA, Densmore JN, Goodbred SJ, Audet DJ (1993) Detailed study of water quality, bottom sediment, and biota associated with irrigation drainage in the Salton Sea area, California, 1988-90. U.S.

Geol Surv, Water-Resour Invest Rept 93-4014, Sacramento, CA

Shuford WD, Warnock N, Molina KC,Sturm KK (2002) The Salton Sea as a critical habitat to migratory and resident waterbirds. Hydrobiologia 473:255-274

Shuford WD, Hickey CM, Safran RJ, Page GW (1996) A review of the status of the white-faced ibis in winter in California. Western Birds 27:169-196

Snyder NFR,Beissinger SR, Fuller MR (1989) Solar radio-transmitters on snail kites in Florida. J Field Ornithol 60:171-177

Steele BB (1980) Reproductive success of white-faced ibis: The effects of pesticides and colony characteristics. MS Thesis. Utah State Univ, Logan, UT

Stickel LF, Wiemeyer SN, Blus LJ (1973) Pesticide residues in eggs of wild birds: Adjustment for loss of moisture and lipid. Bul Environ Contam Toxicol 9:193-196

Wheelwright NT (1986) The diet of American robins: An analysis of U.S. Biological Survey records. Auk 103:710725 
Table 1. Clutch completion dates and associated organochlorine ( $\mu \mathrm{g} / \mathrm{g}$, wet weight) residues in white-faced ibis eggs from various nesting segments at Carson Lake, Nevada, 1985, 1986, 1996 and 2000

\begin{tabular}{|c|c|c|c|c|c|c|c|c|c|c|c|c|}
\hline \multirow[b]{2}{*}{ Year } & \multirow[b]{2}{*}{$\mathrm{N}$} & \multirow[b]{2}{*}{$\begin{array}{l}\text { Mean clutch } \\
\text { completion date }\end{array}$} & \multicolumn{3}{|c|}{ DDE $\mu \mathrm{g} / \mathrm{g}$} & \multicolumn{7}{|c|}{ Incidence $^{\mathrm{a}}$} \\
\hline & & & Geo. Mean & High & $\geq 4 \mu \mathrm{g} / \mathrm{g}$ & DDT & Dieldrin & $\mathrm{HE}$ & Chlordane $^{\mathrm{b}}$ & Toxaphene & HCB & Endrin \\
\hline $1985^{c}$ & 40 & $23 \mathrm{Apr}$ & 3.43 & 21 & $25(63 \%)$ & $7(18 \%)$ & $25(63 \%)$ & 0 & 0 & $1(3 \%)$ & NA & $6(15 \%)$ \\
\hline $1985^{\mathrm{c}}$ & 20 & 21 May & 1.87 & 9 & $6(30 \%)$ & $4(20 \%)$ & $4(20 \%)$ & $1(5 \%)$ & 0 & 0 & NA & $4(20 \%)$ \\
\hline $1986^{\mathrm{c}}$ & 20 & 19 Apr & 3.23 & 28 & $11(55 \%)$ & $11(55 \%)$ & $7(35 \%)$ & 0 & $4(20 \%)$ & $9(45 \%)$ & $3(15 \%)$ & $4(20 \%)$ \\
\hline $1986^{\mathrm{c}}$ & 20 & 1 May & 1.70 & 29 & $7(35 \%)$ & $8(40 \%)$ & $4(20 \%)$ & $4(20 \%)$ & $3(15 \%)$ & $4(20 \%)$ & $10(50 \%)$ & $6(30 \%)$ \\
\hline $1986^{\mathrm{c}}$ & 20 & 15 May & 2.10 & 19 & $6(30 \%)$ & $7(35 \%)$ & $7(35 \%)$ & $4(20 \%)$ & 0 & $1(5 \%)$ & $7(35 \%)$ & $3(15 \%)$ \\
\hline $1986^{\mathrm{c}}$ & 20 & 21 May & 1.53 & 14 & $4(20 \%)$ & $7(35 \%)$ & $4(20 \%)$ & $4(20 \%)$ & $2(10 \%)$ & 0 & $6(30 \%)$ & $3(15 \%)$ \\
\hline $1996^{\mathrm{c}}$ & 20 & 7 May & 2.66 & 12 & $9(45 \%)$ & $12(60 \%)$ & 0 & 0 & $1(5 \%)$ & NA & $2(10 \%)$ & 0 \\
\hline $2000^{\mathrm{d}}$ & 10 & $29 \mathrm{Apr}$ & 3.63 & 8 & $6(60 \%)$ & 0 & $3(30 \%)$ & 0 & 0 & 0 & 0 & 0 \\
\hline
\end{tabular}

$\mathrm{NA}=$ not analyzed, $\mathrm{HE}=$ heptachlor epoxide, $\mathrm{HCB}=$ hexachlorobenzene, Geo. $=$ Geometric

${ }^{\mathrm{a}}$ Number of eggs with concentrations $\geq 0.10 \mu \mathrm{g} / \mathrm{g}$ (the detection limit for 1985-86) for comparative purposes in this table. The detection limit actually $0.01 \mu \mathrm{g} / \mathrm{g}$ in 1996 and 2000 (see later footnote)

${ }^{\mathrm{b}}$ Includes oxychlordane, trans-nonachlor, and cis-nonachlor

${ }^{\mathrm{c}}$ Adapted from Henny (1997)

${ }^{\mathrm{d}}$ This study,number of eggs collected in 2000 with > $0.01 \mu \mathrm{g} / \mathrm{g}$ : HCB (3), dieldrin (8), endrin (8), o,p'-DDD (5), p,p'-DDD (6) 
Table 2. DDE in blood plasma ( $\mu \mathrm{g} / \mathrm{g}$, wet weight) of adult male, early nesting white-faced ibis sampled at Carson Lake, Nevada in 2000 and 2003 , and in earthworms $(\mu \mathrm{g} / \mathrm{kg}$, wet weight) collected on their wintering grounds, 2001-2004

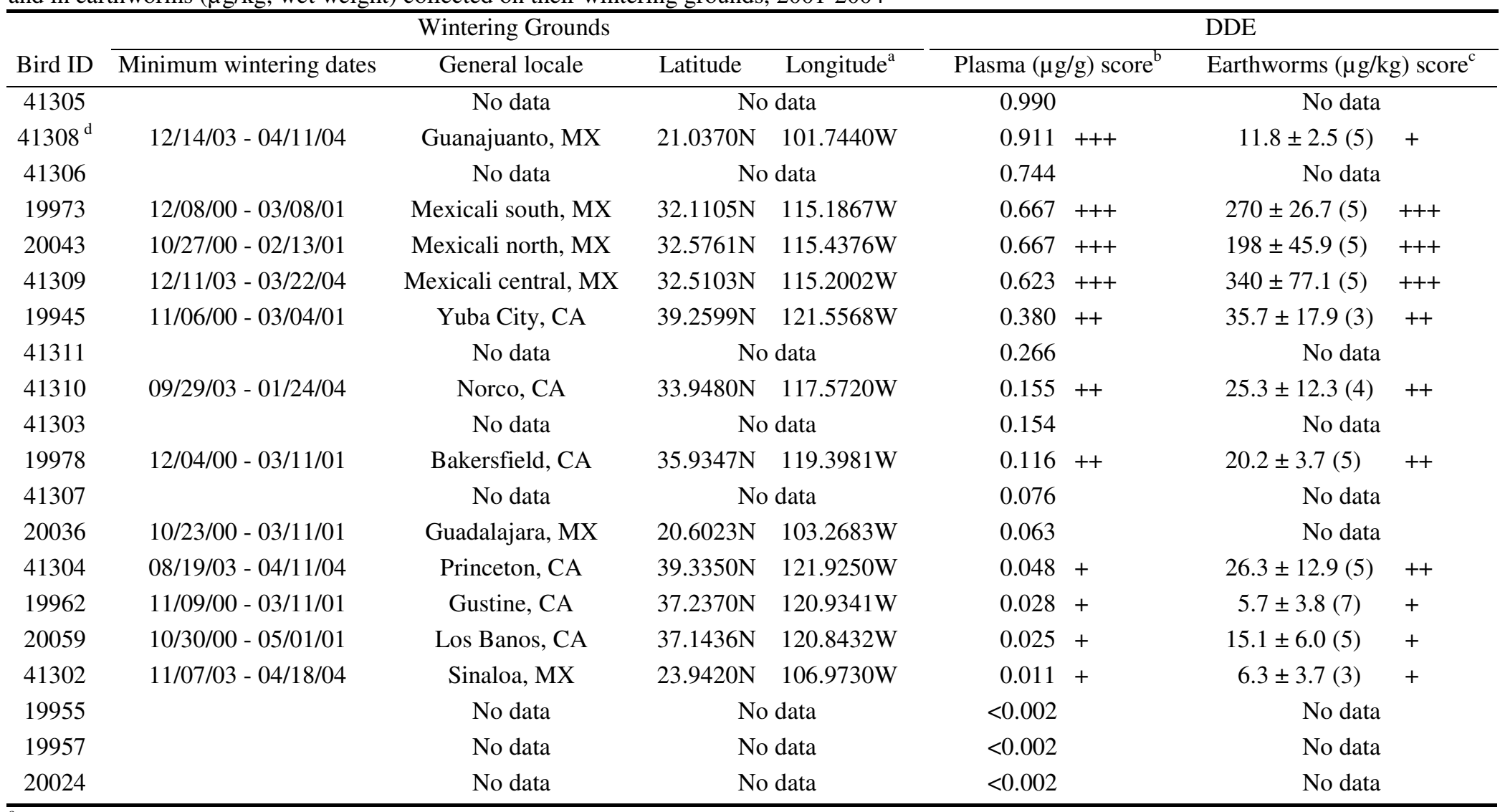

${ }^{a}$ Mean Class 3 location, decimal degrees, WGS 84

${ }^{\mathrm{b}}$ Where comparisons could be made between plasma and earthworms, DDE residues were categorized as follows: (+++ high, ++ medium and + low). Detection Limit $0.002 \mu \mathrm{g} / \mathrm{g}$ ww

${ }^{\mathrm{c}}$ Mean $\pm \mathrm{SE}$, (Number of composite samples)

${ }^{\mathrm{d}}$ The outlier bird shown in Fig. 2 and Fig 3 
Table 3. Avian species present at white-faced ibis wintering sites in Mexicali

Valley, Mexico with high earthworm DDE levels.

\begin{tabular}{ll}
\hline Common Name & Scientific Name \\
\hline Black-necked stilt & Himantopus mexicanus \\
Brown-headed cowbird & Molothrus ater \\
Cattle egret & Bubulcus ibis \\
Gambel's quail & Callipepla gambelli \\
Great egret & Casmerodius albus \\
Great-tailed grackle & Quiscalus mexicanus \\
Killdeer & Charadrius vociferus \\
Mourning dove & Zenaida macroura \\
Northern mockingbird & Mimus polyglottos \\
Red-winged blackbird & Agelaius phoeniceus \\
Snowy egret & Egretta thula \\
Tree swallow & Tachycineta bicolor \\
Vermilion flycatcher & Pyrocephalus rubinus \\
\hline
\end{tabular}

\section{Figure Legends}

Fig 1. Wintering sites of white-faced ibis that nested in 2000 and 2003 at Carson Lake, Nevada, with relative DDE concentrations (see text) in their blood plasma and in earthworms collected at their wintering sites

Fig. 2. Relationship between DDE concentrations in white-faced ibis plasma (wet weight) collected on the breeding grounds and DDE in earthworms (wet weight) on their wintering grounds. Note outlier (०), see text for details

Fig.3. Available information on southward migration of the four white-faced ibis with high concentrations of DDE in blood plasma 
1. Wintering sites of white-faced ibis that nested in 2000 and 2003 at Carson Lake, Nevada, with relative DDE concentrations (see text) in their blood plasma and in earthworms collected at their wintering sites

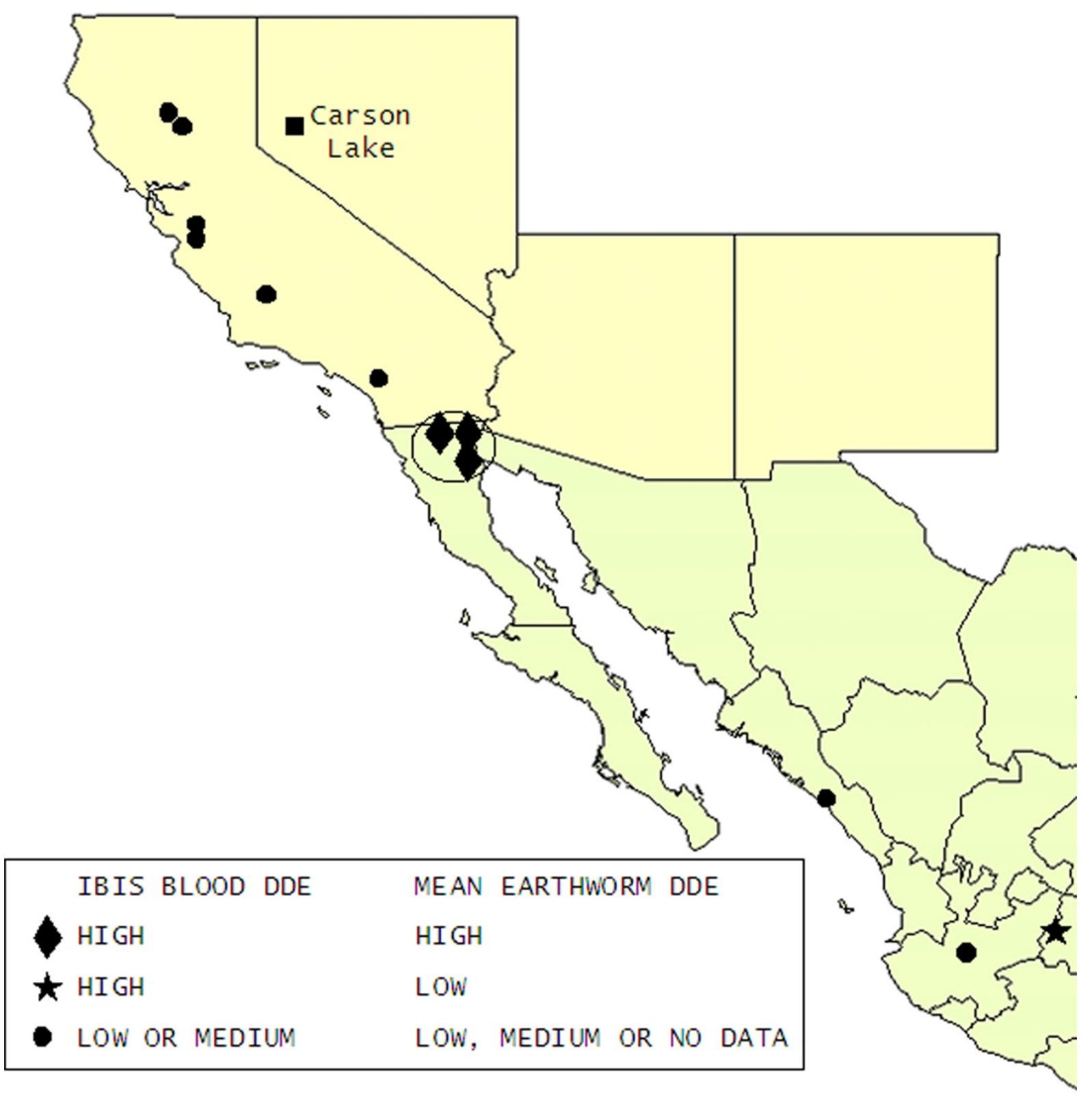




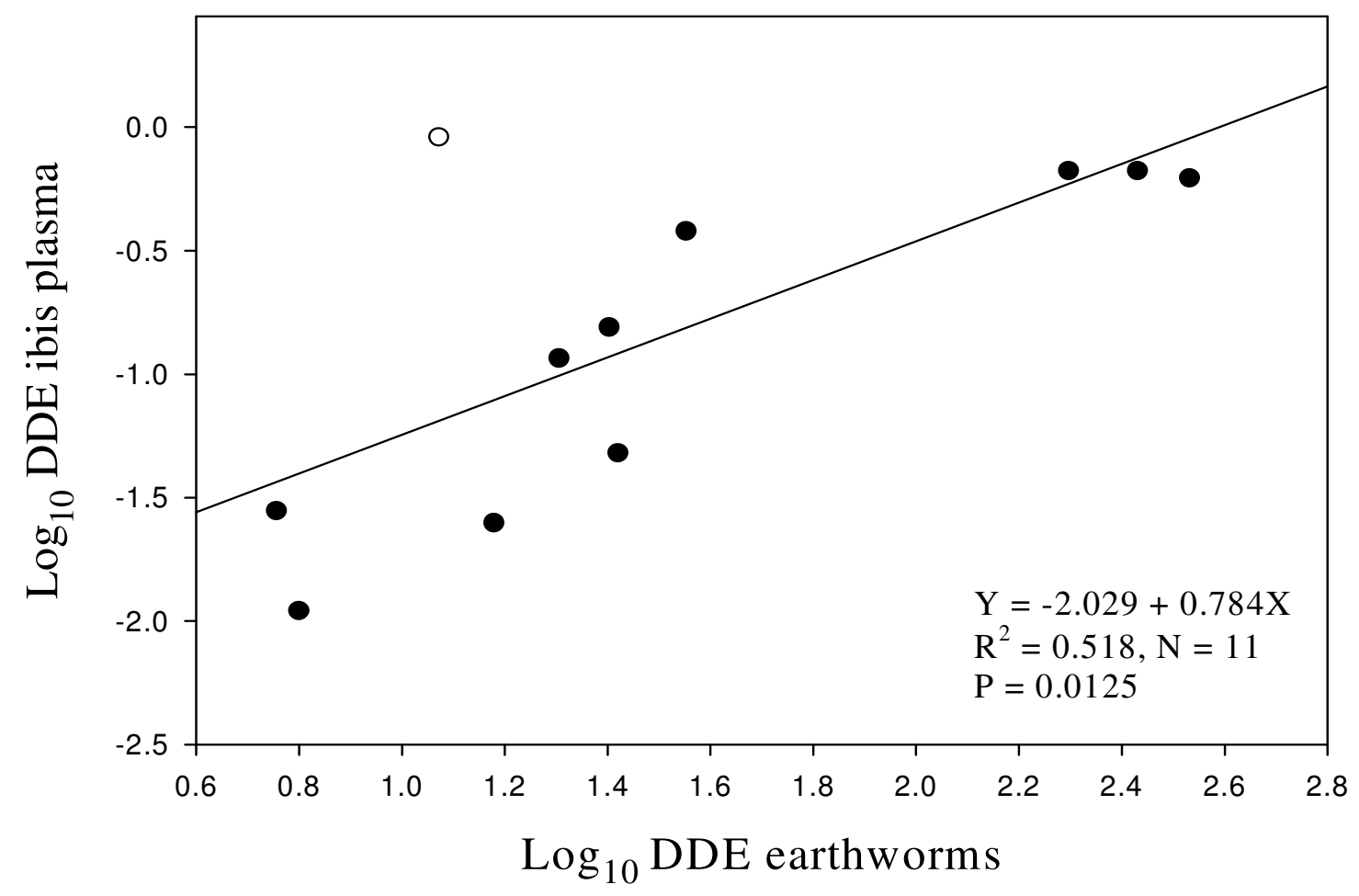

Fig. 2. Relationship between DDE concentrations in white-faced ibis plasma (wet weight) collected on the breeding grounds and DDE in earthworms (wet weight) on their wintering grounds. Note outlier (O), see text for details 
Fig.3. Available information on southward migration of the four white-faced ibis with high concentrations of DDE in blood plasma
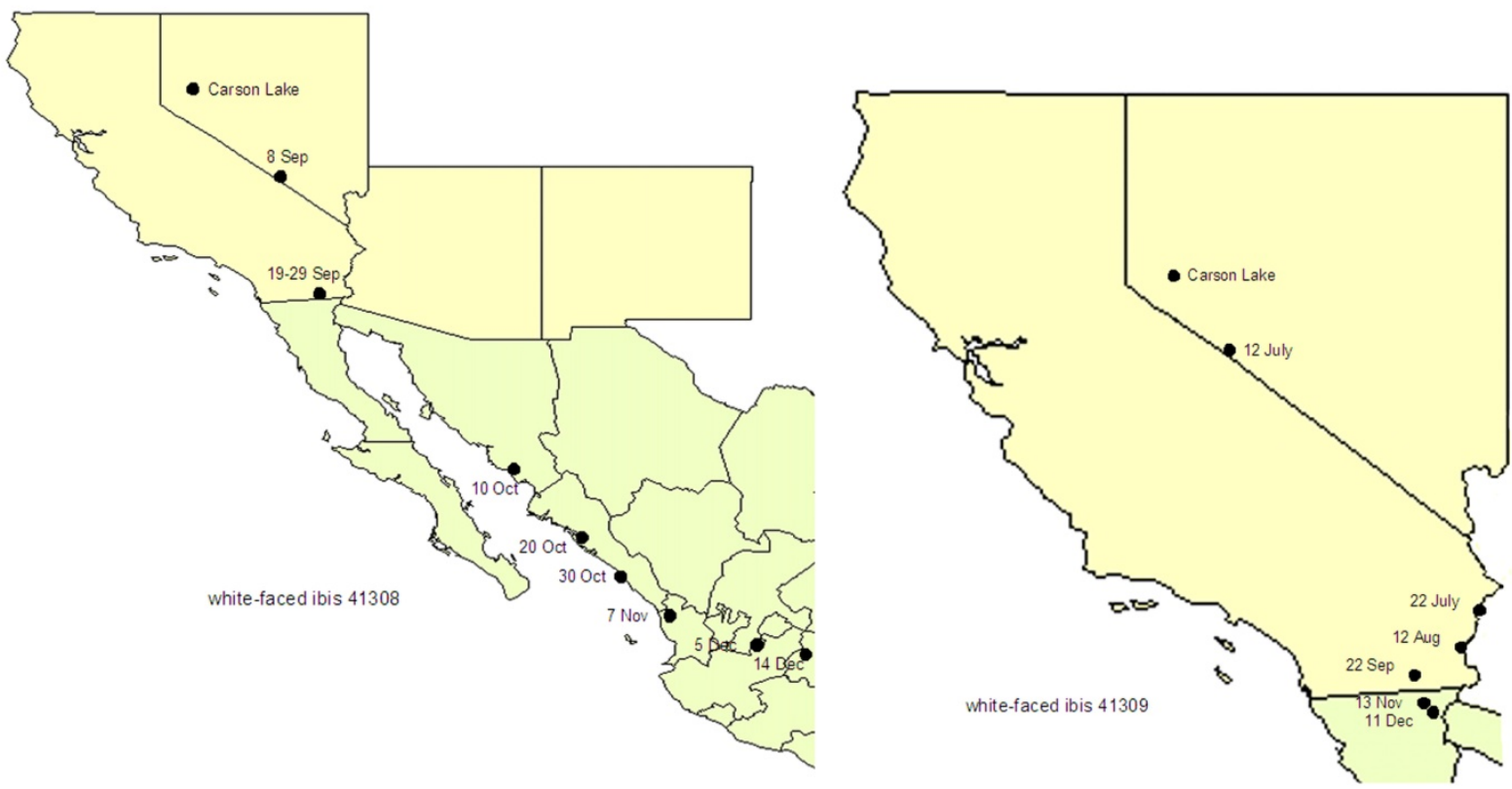

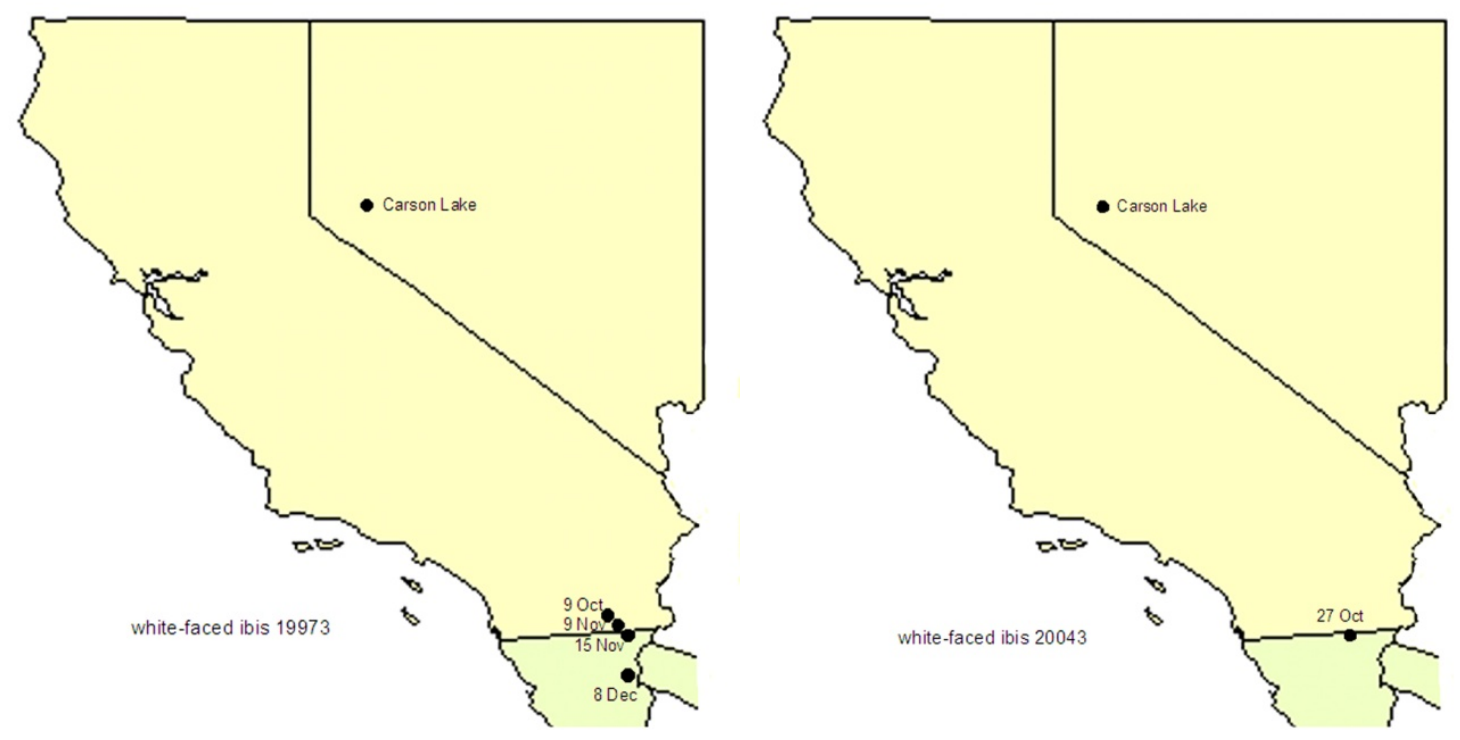